Summary: The aim of this study was to design new soy proteinbased bi-layered co-injection moulded matrix systems aimed to achieve controlled drug delivery. The devices consisted of a drug-free outer layer (skin) and a drug-containing core. The systems overcame the inherent disadvantage of non-linear release associated with diffusion-controlled single-layer matrix devices by providing additional releasing area with time to compensate for the decreasing release rate. As expected, the bilayer devices presented a significant decrease in drug release rate when compared with a correspondent single layer matrix system. The skin thickness and the degree of crosslinking of the core appeared to be very important tools to tailor the release patterns. Furthermore, due to the amphoteric nature of the soy protein, the developed devices evidenced a $\mathrm{pH}$ dependent behaviour. The mechanisms of drug release were also elucidated at two different $\mathrm{pH}$ values: i) $\mathrm{pH}$ 5.0, near the isoelectric point of soy (low matrix solubility); and ii) $\mathrm{pH}$ 7.4, physiological $\mathrm{pH}$ (high matrix solubility). Consequently, changing the release medium from $\mathrm{pH} 5.0$ to $\mathrm{pH} 7.4$ after two hours, led to an abrupt increase in drug release and the devices presented a typical controlled drug delivery profile: slow release/fast release. These evidences may provide for the development of individual systems with different release onsets that in combination may exhibit drug releases at predetermined times in a pre-programmed way. Another possibility is the production of three-layer devices presenting bimodal release profiles (fast release/slow release/fast release) by similar technologies.

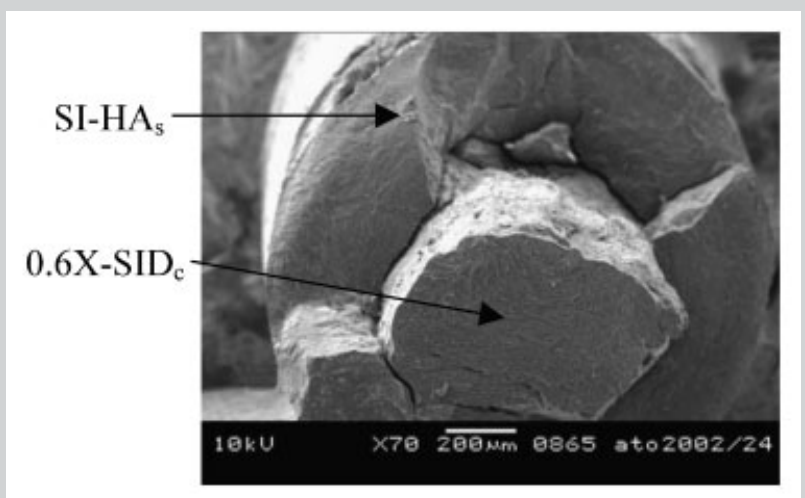

Scanning electron micrograph of a developed bi-layer device.

\title{
Controlled Delivery Achieved with Bi-Layer Matrix Devices Produced by Co-Injection Moulding
}

\author{
Cláudia M. Vaz, ${ }^{* 1}$ Patrick F. N. M. van Doeveren, ${ }^{2}$ Gustavo R. Dias, ${ }^{1}$ Rui L. Reis, ${ }^{1,3}$ António M. Cunha ${ }^{1}$ \\ ${ }^{1}$ Department of Polymer Engineering, University of Minho, Campus de Azurém, 4800-058 Guimarães, Portugal \\ Fax: +351253 510249; E-mail: claudiavaz@dep.uminho.pt \\ ${ }^{2}$ ATO, Agrotechnological Research Institute, PO Box 17, 6700 AA Wageningen, The Netherlands \\ Fax: +31 317 475349; E-mail: patrick.vandoeveren@wur.nl \\ ${ }^{3}$ 3B's Research Group - Biomaterials, Biodegradables and Biomimetics, University of Minho, Campus de Gualtar, \\ 4710-057 Braga, Portugal \\ Fax: +351 253 510249; E-mail: rgreis@ dep.uminho.pt
}

Received: September 23, 2003; Revised: April 1, 2004; Accepted: April 7, 2004; DOI: 10.1002/mabi.200300060

Keywords: bi-layer devices; (co-)injection moulding; drug delivery systems; soy protein; theophylline

\section{Introduction}

It is well recognized that controlled-release dosage forms may offer several advantages over immediate release formulations of the same drug. The most common controlled delivery system containing uniformly dissolved or dispersed drug are tablets and particles because of its effectiveness as well as low cost and ease of manufacturing. ${ }^{[1]}$ Nevertheless, their release behaviour is intrinsically nonlinear in nature, with continuously diminishing release rate. ${ }^{[2,3]}$ This is a direct result from a decreasing release rate with time due to an increase in diffusion resistance and/or a decrease in effective area at the diffusion front. ${ }^{[4]}$ With the emergent need for optimization of therapy, systems providing programmable rates of release other than the typical first-order are becoming more imperative. ${ }^{[5]}$ For this reason, constant-rate delivery has always been one of the main targets of controlled-release systems, especially for drugs with a narrow therapeutic index. ${ }^{[5]}$ Over the last years, considerable efforts have been spent in the development of new 
delivery concepts in order to achieve the desired controlledrelease. Examples included the use of geometry factors (donut shape, core in cup, biconcave,...), erosion/dissolution control and swelling control mechanisms (multi-layer tablets) and matrix-membrane combinations. ${ }^{[1,4,6-16]}$ However, some of those systems are difficult or impractical to manufacture, environmentally unfriendly and presenting low versatility in terms of formulations.

In a previous study, soy-protein bi-layer cylindrical devices of very small dimensions were produced using an innovative technique in the field, a two-material coinjection moulding. ${ }^{[17]}$ This technique allowed, in one step, the joining of two polymers into a moulded device that did not require any further finishing operations. ${ }^{[17]}$ The immediate results were devices with a well-defined geometry and skin/core morphology. ${ }^{[17]}$ Soy protein was selected as the matrix former due to its high availability ${ }^{[18]}$ good melt processability, ${ }^{[19]}$ high thermal stability ${ }^{[19]}$ and non-cytotoxicity, ${ }^{[20]}$ features that distinguish positively soy from other protein-like materials already used in the pharmaceutical field. ${ }^{[21-27]}$ Therefore, the second goal to be reached is to investigate the suitability of the developed bi-layer devices to attain controlled-delivery behaviour. Consequently, the main targets of this study were: i) compare the release patterns of the previously investigated single layer devices with those from the newly developed bi-layer ones; ii) to investigate parameters such as crosslinking degree, skin/core ratios and $\mathrm{pH}$ of the immersion solution affecting the drug delivery profiles; and iii) validate the suitability of the co-injection moulded bi-layer devices to achieve controlled drug release.

\section{Experimental Part}

\section{Materials}

The following materials were used as received from the manufacturers: soy protein isolate (amorphous, 83.4 wt.- $\%$ protein on dry basis, Loders Crocklaan BV, Wormeveer, The Netherlands), glycerol, glyoxal (40 vol.-\%), $o$-phthaldialdehyde (OPA) and anhydrous theophylline (TH, $\mathrm{C}_{7} \mathrm{H}_{8} \mathrm{~N}_{4} \mathrm{O}_{2}$, purity $>98 \%$, Figure 1) (from Sigma-Aldrich Chemie BV, Zwijndrecht, The Netherlands).<smiles>Cn1c(=O)c2nc[nH]c2n(C)c1=O</smiles>

Theophylline

Figure 1. Chemical structure of theophylline (TH, $\left.\mathrm{C}_{7} \mathrm{H}_{8} \mathrm{~N}_{4} \mathrm{O}_{2}\right)$.
Hydroxylapatite (a non-sintered bone like ceramic filler with an average particle size $<20 \mu \mathrm{m}$ ) was supplied by CAM Implants BV, Leiden, The Netherlands. All the other reagents used in the experiments were of analytical grades.

Glyoxal was the selected crosslinker due to its dialdehyde functionality able to react with the free $\varepsilon$-amine groups of the lysine (or hydroxylysine) residues of soy, (Equation (1):

2 Prot $-\mathrm{NH}_{2}+\mathrm{H}-\mathrm{C}-\mathrm{C}-\mathrm{H} \longrightarrow$ Prot-N=CH-CH=N-Prot $+2 \mathrm{H}_{2} \mathrm{O}$

Moreover, glyoxal has been shown to be less toxic for human cells than the most commonly used formaldehyde and glutaraldehyde crosslinkers. ${ }^{[28]}$

\section{Premix Preparation}

Premixes of the matrix material (soy protein isolate), filler and drug were prepared prior to processing. The constituents of each formulation were weighed and transferred into a mixer container. This was followed by mixing all the compounds for $15 \mathrm{~min}$ at room temperature $\left(25^{\circ} \mathrm{C}\right)$ using a Bear Varimixer (Bear, Denmark) equipped with a low shear spiral-mixing tool at a speed of $45 \mathrm{rpm}$.

\section{Melt-Extrusion}

The solid premixes were converted into plastic materials, with encapsulated TH, by extrusion. ${ }^{[2-32]}$ They were directly fed into a co-rotating twin-screw extruder (Berstorff, Hannover, Germany, $D=25 \mathrm{~mm}$ and $L=40 D$ ). The liquids, such as plasticizers (glycerol and water (or a buffer solution of acetic acid $\left(\mathrm{CH}_{3} \mathrm{COOH}\right) /$ sodium acetate $\left(\mathrm{CH}_{3} \mathrm{COONa}\right) 200 \times 10^{-3} \mathrm{~m}$, $\mathrm{pH} 4)$ ) and crosslinker (glyoxal), were concurrently injected into the second feeding zone of the extruder barrel with a piston pump (Pro Minet, Verder BV, The Netherlands). Table 1

Table 1. Composition of the investigated matrices (all quantities in phg (parts/100 g protein)).

\begin{tabular}{|c|c|c|c|c|}
\hline & \multicolumn{4}{|c|}{ Formulation } \\
\hline & $\mathrm{SI}_{\mathrm{tp}}{ }^{\mathrm{a})}$ & $\operatorname{SID}_{\mathrm{tp}}^{\mathrm{b})}$ & $0.6 \mathrm{X}-\mathrm{SID}_{\mathrm{tp}}{ }^{\mathrm{c})}$ & SI-HA ${ }_{t p}{ }^{d}$ \\
\hline Soy & 100 & 100 & 100 & 100 \\
\hline Glycerol & 10 & 10 & 10 & 10 \\
\hline Water & 30 & 30 & 30 & 30 \\
\hline Glyoxal & - & - & 0.6 & - \\
\hline Theophylline & - & 20 & 20 & - \\
\hline Hydroxylapatite & - & - & - & 30 \\
\hline $\mathrm{pH}$ & $\approx 7.0$ & $\approx 7.0$ & $\approx 7.0$ & $\approx 7.0$ \\
\hline $\begin{array}{l}\text { Free amine group } \\
\text { content }(\%)\end{array}$ & - & $97.6 \pm 0.5$ & $55.9 \pm 1.0$ & - \\
\hline \multicolumn{5}{|c|}{$\begin{array}{l}\text { a) } \mathrm{SI}_{\mathrm{tp}} \text { : thermoplastic soy matrix. } \\
\text { b) } \mathrm{SID}_{\mathrm{tp}} \text { : thermoplastic soy matrix with encapsulated theophylline. } \\
\text { c) } 0.6 \mathrm{X}-\mathrm{SID}_{\mathrm{tp}} \text { : glyoxal crosslinked thermoplastic soy matrix with } \\
\text { encapsulated theophylline. } \\
\text { d) } \mathrm{SI}_{\mathrm{H}} \mathrm{H}_{\mathrm{tp}} \text { : hydroxylapatite reinforced thermoplastic soy matrix } \\
\text { with encapsulated theophylline. }\end{array}$} \\
\hline
\end{tabular}


presents all the formulations prepared during this experiment and the respective codes.

The extrusion conditions were based on preliminary research work. ${ }^{[29-32]}$

\section{Sample Preparation}

Axi-symmetrical dumbbell-like skin/core specimens of $1.5 \mathrm{~mm}$ in diameter $\left(\mathrm{SI}_{\mathrm{s}} / \mathrm{SID}_{\mathrm{c}}, \mathrm{SID}_{\mathrm{s}} / 0.6 \mathrm{X}-\mathrm{SID}_{\mathrm{c}}, \mathrm{SI}_{-\mathrm{HA}} / \mathrm{SID}_{\mathrm{c}}\right.$ and SI-HA $/ 0.6 \mathrm{X}-\mathrm{SID}_{\mathrm{c}}$, where $s$ and $c$ refers to the skin and core, respectively) were co-injection moulded in a 2 material Ferromatik-Milacron K85 machine. The machine was operated in mono-sandwich mode. ${ }^{[17]}$ The processing conditions used for the production of all the mouldings were previously optimised. ${ }^{[17]}$

Conventional injection moulding was also performed with the $\mathrm{SID}_{\mathrm{tp}}$ and $0.6 \mathrm{X}-\mathrm{SID}_{\mathrm{tp}}$ for comparison purpose.

\section{Protein Solubility}

A 0.1 wt.- $\%$ protein solution was prepared by dispersing about $50 \mathrm{mg}$ of protein powders in $45 \mathrm{~g}$ of demineralized water. The dispersion was magnetically stirred until complete dispersion of the powder (approximately 30 minutes). The $\mathrm{pH}$ values of the solutions were adjusted to the desired $\mathrm{pH}$ values (in the case, $\mathrm{pH}$ values of 3, 4, 5, 6, 7 and 9) using $0.1 \mathrm{~m} \mathrm{HCl}$ or $0.1 \mathrm{M}$ $\mathrm{NaOH}$. The solutions were again stirred during 1 hour and the $\mathrm{pH}$ values verified and adjusted if necessary. When the $\mathrm{pH}$ values were stable, the total weight was brought to $50 \mathrm{~g}$ with additional water. Subsequently, the dispersions were centrifuged for $10 \mathrm{~min}$ at $13500 \mathrm{rpm}$. The protein content in the supernatant was determined by Kjeldahl analysis as explained in section 2.7. However, the digestion conditions were different for these liquid samples and composed of three steps: i) $160^{\circ} \mathrm{C}$ during $1 \mathrm{~h}$; ii) $260^{\circ} \mathrm{C}$ during another $1 \mathrm{~h}$; and iii) $420^{\circ} \mathrm{C}$ during another 50 minutes. The protein solubility at the different $\mathrm{pH}$ values was calculated according to:

$$
\text { Solubility }(\%)=\left(N_{\text {sup }} / N_{\text {tot }}\right) \times 100
$$

The protein content of the supernatant $\left(N_{\text {sup }}\right)$ was calculated by Equation (3):

$N_{\text {sup }}(\%)=\left\{\left[\left(\mathrm{V}_{\mathrm{HCl}} \times 0.1 \times 14 \times 6.25\right) / W_{\mathrm{d}}\right] \times 1000\right\} \times 100$

$W_{\mathrm{d}}$ is the weight of the supernatant tested. The $N_{\text {tot }}$ corresponds to the protein content of the dry samples used to prepare the dispersions and is calculated by Equation (4):

$N_{\text {tot }}(\%)=\left[\left(\mathrm{V}_{\mathrm{HCl}} \times 0.1 \times 14 \times 6.25\right) / W_{\mathrm{D}}\right] \times 100$

Where, $\mathrm{V}_{\mathrm{HCl}}$ is the volume of $0.1 \mathrm{M} \mathrm{HCl}$ used during the Kjeldahl titration, 14 is the atomic mass of nitrogen $(N)$ and 6.25 the Kjeldahl factor of soy. $W_{\mathrm{D}}$ is the dry weight of the protein powder sample previously tested.

\section{Crosslinking Degree}

The crosslinking degree of the produced specimens was evaluated through the quantification of the reduction of the res- pective free amine-group content. This was determined using the previously described OPA (o-phthaldialdehyde) method. ${ }^{[29-31]}$

\section{Morphology}

The devices morphology was assessed before and after the release tests by observation of the respective cross-sections using a scanning electron microscope (Leica Cambridge S360, Cambridge, UK). The specimens were first dried under vacuum, afterwards cryogenically broken and finally gold sputtered before observation.

\section{Drug Release Studies}

The release kinetics of the model drug TH from the bi-layer devices was also assessed. Randomly selected batches of specimens were immersed, at $37^{\circ} \mathrm{C}$, in isotonic saline solutions (ISS, $\mathrm{NaCl}, 9 \mathrm{~g} \cdot 1^{-1}+1$ wt.- $\%$ sodium azide $\left(\mathrm{NaN}_{3}\right)$ ) buffered at two different $\mathrm{pH}$ values:

i) $\mathrm{pH} 5.0 \pm 0.03: 0.2 \mathrm{M}$ acetic acid $\left(\mathrm{CH}_{3} \mathrm{CO}_{2} \mathrm{H}\right) / 0.2 \mathrm{M}$ sodium acetate $\left(\mathrm{CH}_{3} \mathrm{CO}_{2} \mathrm{Na}\right)$ buffer; and ii) $\mathrm{pH} 7.4 \pm 0.02$ : $0.2 \mathrm{M}$ tris(hydroxymethyl)aminomethane/0.2 $\mathrm{m}$ hydrochloric acid ( $\mathrm{HCl})$ buffer $(0.2 \mathrm{~m}$ Tris- $\mathrm{HCl}$ buffer $)$.

At preset times $1 \mathrm{ml}$ of each solution was taken out and replaced by $1 \mathrm{ml}$ of fresh solution. The solution was then carefully filtered using a Microcon filter (Amicon, The Netherlands) of $10 \mathrm{kD}$ mesh. The supernatant was assayed for released of TH at $273 \mathrm{~nm}$ using an Alliance HPLC-UV System (Water Cromatography BV, The Netherlands) coupled with a Waters 2690 Separations Module and a Waters 996 Photodiode Array Detector. The selected mobile phase corresponded to a mixture of water/acetonitrile (80:20 vol.-\%) used at a flow rate of $0.75 \mathrm{ml} \cdot \mathrm{min}^{-1}$. A Chrompack Varian Hypersyl $5 \mu \mathrm{m}$ ODS column of $150 \times 4.6 \mathrm{~mm}$ was used in combination with a $1 \mathrm{~cm}$ pre-column. All experiments were conducted in triplicate.

\section{Statistics}

Result data were expressed as mean \pm standard error of the mean. An unpaired $t$ test (Student's $t$ test) was performed, considering a $P<0.05$ as statistically significant.

\section{Results and Discussion}

\section{Controlled Release from Bi-Layer Devices}

The aim of this study was two achieve a controlled release from bi-layer matrices, exhibiting first a slow release and then a fast release. The investigated drug containing SID $_{\text {tp }}$ and $0.6 \mathrm{X}-\mathrm{SID}_{\text {tp }}$ matrices were used as the drug-containing inner layers to provide both slow release (in acidic surroundings) and fast release (in neutral surroundings). ${ }^{[33]}$ In order to further hinder drug diffusion out of the device, a soy protein-based drug-free outer layer was used. The crosssections of the bi-layer devices can be seen in Figure 2.

In general, the systems presented a good skin/core adhesion and well-defined skin/core geometry. The differences 


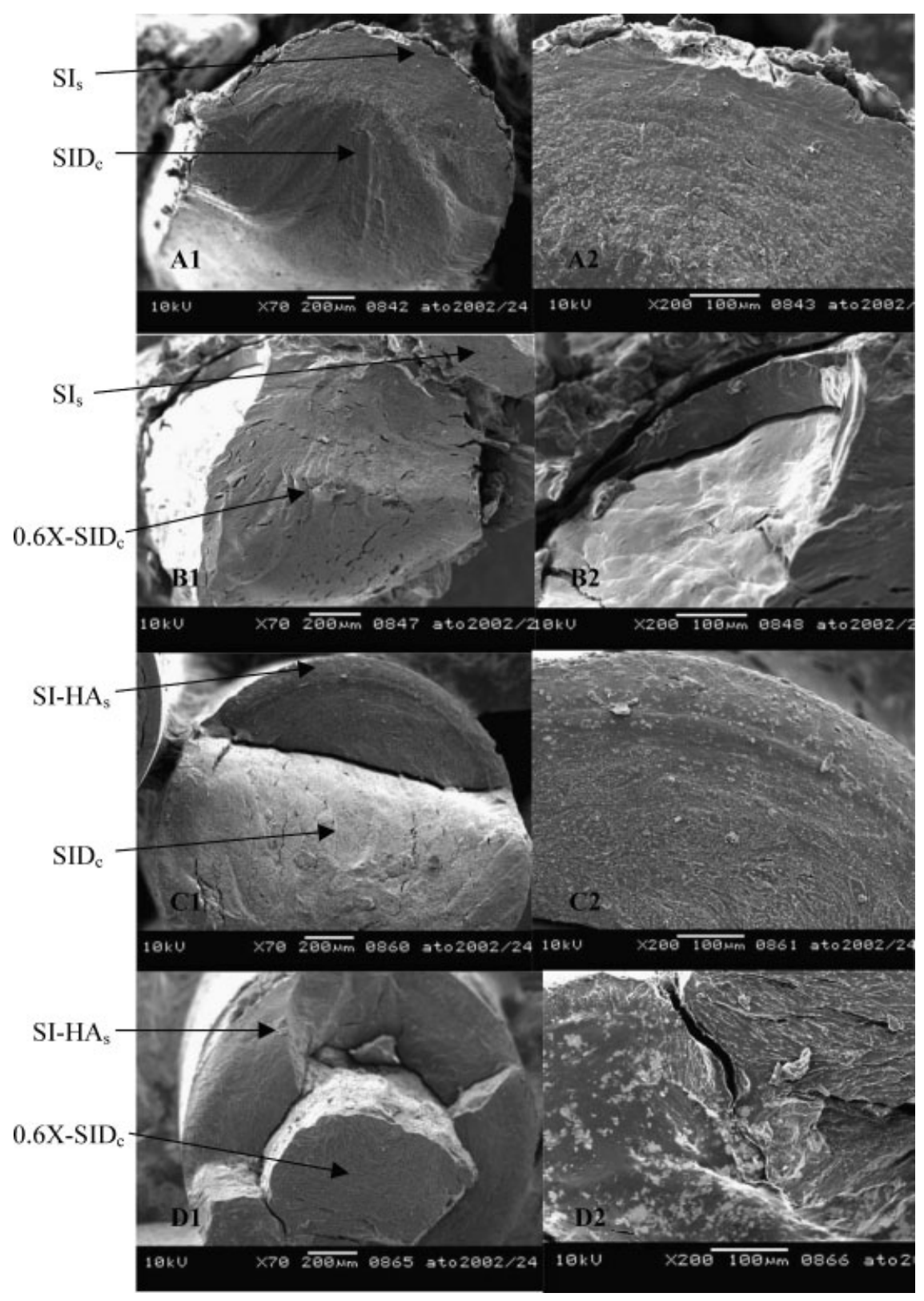

Figure 2. Scanning electron micrographs of the developed bi-layer devices: A1) $\mathrm{SI}_{\mathrm{S}} / \mathrm{SID}_{\mathrm{c}^{-}}$ general view; A2) $\mathrm{SI}_{\mathrm{s}} / \mathrm{SID}_{\mathrm{c}}$-detail of the skin/core interface; $\left.\mathrm{B} 1\right) \mathrm{SI}_{\mathrm{s}} / 0.6 \mathrm{X}-\mathrm{SID}_{\mathrm{c}}$-general view; B2) $\mathrm{SI}_{\mathrm{s}} / 0.6 \mathrm{X}-\mathrm{SID}_{\mathrm{c}}$-detail of the skin/core interface; C1) SI-HA $/ \mathrm{SID}_{\mathrm{c}}$-general view;

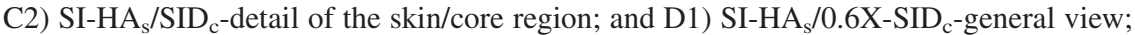
D2) $\mathrm{SI}_{-} \mathrm{HA}_{\mathrm{s}} / 0.6 \mathrm{X}-\mathrm{SID}_{\mathrm{c}}$-detail of the skin/core region.

in skin thicknesses are also evident. The skin/core ratios of the devices with the crosslinked cores $\left(\mathrm{SI}_{\mathrm{S}} / 0.6 \mathrm{X}-\mathrm{SI}_{\mathrm{c}}\right.$ and SI$\mathrm{HA}_{\mathrm{s}} / 0.6 \mathrm{X}-\mathrm{SID}_{\mathrm{c}}$ ) (Figures $2 \mathrm{~B}$ and D) were higher than those of the devices with non-crosslinked core $\left(\mathrm{SI}_{\mathrm{s}} / \mathrm{SID}_{\mathrm{c}}\right.$ and SI$\mathrm{HA}_{\mathrm{s}} / \mathrm{SID}_{\mathrm{c}}$ ) (Figures $2 \mathrm{~A}$ and $\mathrm{C}$ ). The reason for these differences can be found elsewhere. ${ }^{[17]}$

As can be observed in Figure 3, the addition of the drugfree outer layer $\left(\mathrm{SI}_{\mathrm{tp}}\right)$ to the inner layers $\left(\mathrm{SID}_{\mathrm{tp}}\right.$ and $0.6 \mathrm{X}$ $\mathrm{SID}_{\mathrm{tp}}$ ) by co-injection moulding resulted in a significant decrease of the release rates in both media (ISS + acetate buffer $\mathrm{pH} 5.0$ and ISS + Tris/HCl buffer $\mathrm{pH} 7.4$ ).

The initial burst releases observed for the matrix systems $\mathrm{SID}_{\mathrm{tp}}$ and $0.6 \mathrm{X}-\mathrm{SID}_{\mathrm{tp}}$ could now be efficiently controlled. Furthermore, the bi-layer device with the crosslinked core $\left(\mathrm{SI}_{\mathrm{s}} / 0.6 \mathrm{X}-\mathrm{SID}_{\mathrm{c}}\right)$ proved to be even more efficient than the bilayer device $\mathrm{SI}_{\mathrm{s}} / \mathrm{SID}_{\mathrm{c}}$ on decreasing the total release rates. This fact must relate with: i) difference in core's crosslinking density and respective solubility as a function of 

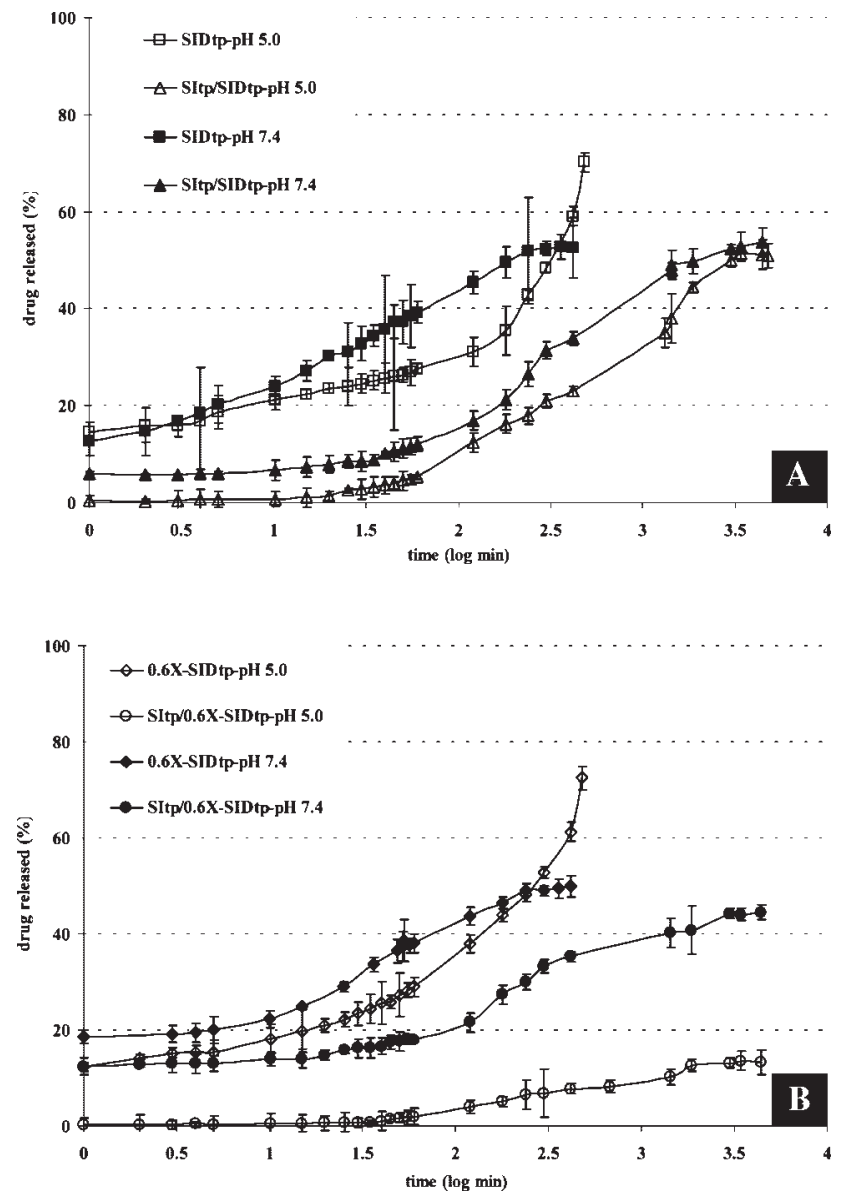

Figure 3. Effect of the addition by co-injection moulding of: A) drug-free layer $\left(\mathrm{SI}_{\mathrm{s}}\right)$ on the release kinetics of theophylline from $\mathrm{SID}_{\mathrm{c}}(P<0.05)$; and $\left.\mathrm{B}\right)$ drug-free layer $\left(\mathrm{SI}_{\mathrm{s}}\right)$ on the release kinetics of theophylline from $0.6 \mathrm{X}-\mathrm{SID}_{\mathrm{c}}(P<0.05)$. Both tested in an ISS + acetate buffer $\mathrm{pH} 5.0$ and in an ISS + Tris/HCl buffer $\mathrm{pH} 7.4$ (ISS, isotonic saline solution, $9 \mathrm{~g} / \mathrm{l} \mathrm{NaCl}+1 \%$ sodium azide $\left.\left(\mathrm{NaN}_{3}\right)\right)$.

$\mathrm{pH}$ (Figure 4); ${ }^{[33]}$ and ii) difference in skin's thickness (Figure 2). In fact, the skin/core ratio of the system $\mathrm{SI}_{\mathrm{s}} /$ $0.6 \mathrm{X}-\mathrm{SID}_{\mathrm{c}}$ is higher than that of $\mathrm{SI}_{\mathrm{s}} / \mathrm{SID}_{\mathrm{c}}$, assuming the respective values of $0.33 \pm 0.07$ and $0.11 \pm 0.04$.

Nevertheless, all the release studies discussed above were conducted either in ISS + acetate buffer pH 5.0 or ISS + Tris/HCl buffer $\mathrm{pH}$ 7.4. However, to achieve a controlled release system (slow release/fast release); it is of interest to test the effect of a change in a release medium after a certain period of time. In Figure 5 the cumulative amounts of TH released from the matrix devices (SID tp $_{\text {and }}$ a.6X-SID ${ }_{\mathrm{tp}}$ ) and the bi-layer devices $\left(\mathrm{SI}_{\mathrm{s}} / \mathrm{SID}_{\mathrm{c}}\right.$ and $\mathrm{SI}_{\mathrm{s}} / 0.6 \mathrm{X}-\mathrm{SID}_{\mathrm{c}}$ ) in ISS + acetate buffer $\mathrm{pH} 5.0$ and ISS + Tris/ $\mathrm{HCl}$ buffer $\mathrm{pH}$ 7.4 are displayed (medium change after 120 minutes).

As expected, the release rates significantly increased for both systems after those 2 hours. Besides, it can be observed that the presence of the drug-free skin layer in the bi-material devices had the additional desired effect of in-

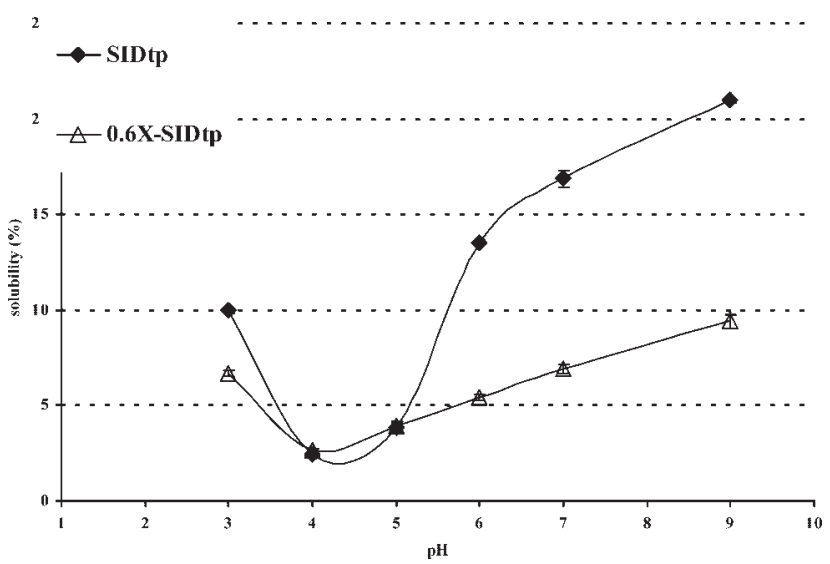

Figure 4. Solubility profiles of the soy matrices $\operatorname{SID}_{\mathrm{tp}}(\triangleleft)$ and $0.6 \mathrm{X}-\mathrm{SID}_{\mathrm{tp}}(\triangle)$ as a function of $\mathrm{pH}$.

creasing the sharpness of the change in $\mathrm{TH}$ release rate, specially the system $\mathrm{SI}_{\mathrm{S}} / 0.6 \mathrm{X}-\mathrm{SID}_{\mathrm{c}}$, and the systems presented the required controlled release behaviour (Figure 5).

In order to provide a faster initial release rate, the SI skin material of the bi-layer devices was replaced by SI-HA. As reported in a previous study, ${ }^{[33]}$ the hydroxylapatite tends to suffer a partial dissolution when in contact with the release media, thus increasing the matrix porosity. Due to the increased interfacial area, it is expected that when the drug reaches this layers it would diffuse faster than it would in SI, increasing as desired the release rate. However, from the analysis of the Figure 6, it is possible to conclude that the opposite effect occurred.

The main reason for this evidence relays on skin thickness differences. The skin/core ratios of the bi-layer systems $\mathrm{SIHA}_{\mathrm{s}} / \mathrm{SID}_{\mathrm{c}}$ and $\mathrm{SIHA}_{\mathrm{s}} / 0.6 \mathrm{X}-\mathrm{SID}_{\mathrm{c}}(0.41 \pm 0.02$ and $0.51 \pm 0.11$, respectively) were considerably higher than those for $\mathrm{SI}_{\mathrm{s}} / \mathrm{SID}_{\mathrm{c}}$ and $\mathrm{SI}_{\mathrm{s}} / 0.6 \mathrm{X}-\mathrm{SID}_{\mathrm{c}}(0.11 \pm 0.04$ and $0.33 \pm 0.07$, respectively). The basis of this variation in skin/core ratios is related with the different viscosities of the studied materials. ${ }^{[17]}$

Besides, for both four systems the desired controlled release (slow release/fast release) could be achieved, illustrating the efficiency of this new type of co-injection moulded bi-layer devices.

\section{Conclusions}

A new type of polymer matrices providing controlled release has been developed using an innovative technique in the field: co-injection moulding. The major advantages of these systems may include: i) easiness of production (especially at industrial scale); ii) suitability for a large variety of polymeric matrices; iii) applicability to different types of drugs; iv) precise control of the skin/core ratio by adjustment of the processing parameters; v) biodegradability; and vi) the possibility to achieve therapeutic blood 

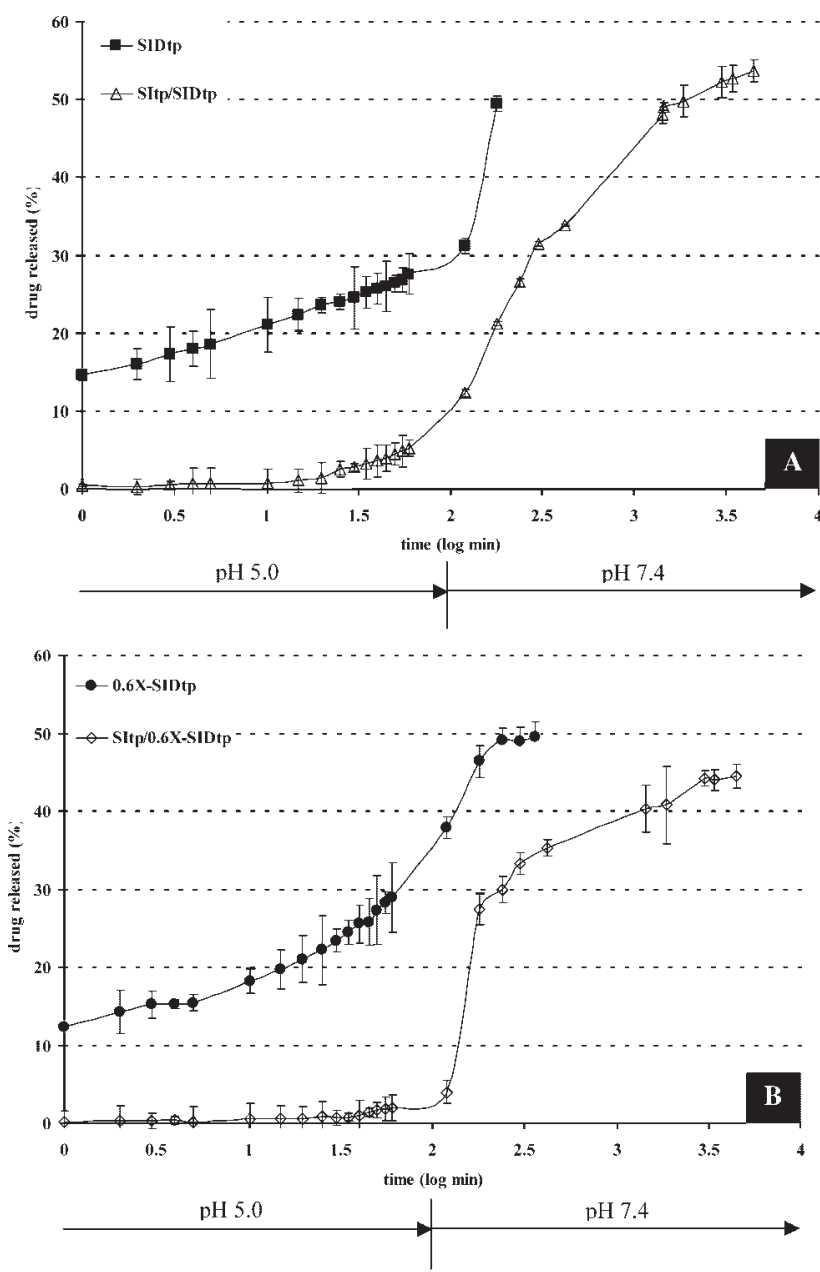

Figure 5. Effect of release medium change from ISS + acetate buffer $\mathrm{pH} 5.0$ to ISS + Tris/ $\mathrm{HCl}$ buffer $\mathrm{pH} 7.4$ after 2 hours on the theophylline release from $(P<0.05)$ : A) a single system $\operatorname{SID}_{\mathrm{tp}}$ and a bi-layer system $\mathrm{SI}_{\mathrm{S}} / \mathrm{SID}_{\mathrm{c}}$; and $\mathrm{B}$ ) a single system $0.6 \mathrm{X}-\mathrm{SID}_{\mathrm{tp}}$ and a bi-layer system $\mathrm{SI}_{\mathrm{s}} / 0.6 \mathrm{X}-\mathrm{SID}_{\mathrm{c}}$.

levels similar to those obtained by administration of two smaller doses over an extended period of time. Various parameters have been identified as potential tools to regulate the time of drug release onset, such as crosslinking degree and skin thickness. These evidences may provide for the development of individual systems with different release onsets (e.g. a system combining high crosslinking degree and high skin thickness would present a more delayed release onset than a non-crosslinked system with a thin skin layer). By combining individual systems with different release onsets, a therapeutic system may be developed exhibiting drug releases at predetermined times in a pre-programmed way. Another possibility is the production of three-layer devices by technologies such as push-pull or co-injection moulding/deep-coating. In these circumstances, if the third outer layer is a drug containing fast disintegrating layer, it would be eventually possible to produce new multi-layer devices
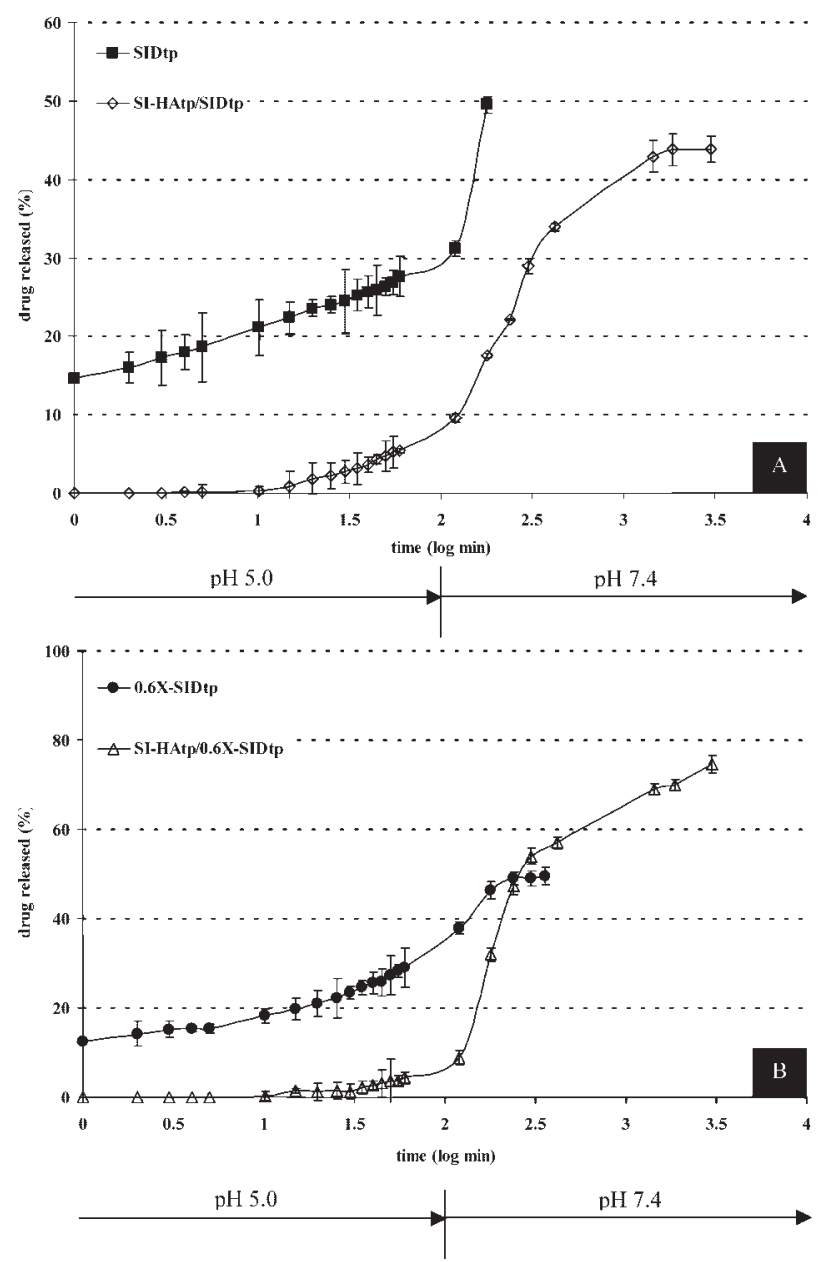

Figure 6. Effect of release medium change from ISS + acetate buffer $\mathrm{pH} 5.0$ to ISS + Tris/ $\mathrm{HCl}$ buffer $\mathrm{pH} 7.4$ after 2 hours on the theophylline release from $(P<0.05)$ : A) a single system $\operatorname{SID}_{\mathrm{tp}}$ and a bi-layer system SI-HA $/$ SID $_{c}$; and B) a single system $0.6 \mathrm{X}-\mathrm{SID}_{\mathrm{tp}}$ and a bi-layer system SI-HA $_{\mathrm{s}} / 0.6 \mathrm{X}-\mathrm{SID}_{\mathrm{c}}$.

presenting bi-modal release profiles (fast release/slow release/fast release).

However, in all cases, the in vivo performance of presented systems will always strongly depend on the variability of the $\mathrm{pH}$ of the release site.

Acknowledgement: C. M. V. acknowledges the Portuguese Foundation for Science and Technology (FCT), Ministry of Science and Technology, Portugal, for the attribution of a personal PRAXIS XXI PhD Grant. The authors are also very grateful to Dimitre Tchalamov for his precious help during the elaboration of the work.

[1] M. P. Danckwerts, Int. J. Pharm. 1994, 112, 37.

[2] J. Siepmann, K. Podual, M. Sriwongjanya, N. A. Peppas, Pharm. Res. 1999, 16, 1748. 
[3] J. Siepmann, K. Podual, M. Sriwongjanya, N. A. Peppas, R. Bodmeier, J. Pharm. Sci. 1999, 88, 65.

[4] R. A. Lipper, W. I. Higuchi, J. Pharm. Sci. 1977, 66, 163.

[5] L. Lee, "Diffusion Controlled Matrix Systems", in: Treatise on Controlled Drug Delivery, A. Kydonieus, Ed., Marcel Dekker Inc., New York 1992, p. 155.

[6] C. Kim, Pharm. Res. 1995, 12, 1045.

[7] A. Y. Benkorah, J.-N. McMullen, J. Control. Rel. 1994, 32, 155.

[8] U. Conte, L. Maggi, P. Colombo, A. L. Manna, J. Controlled Release 1993, 26, 39.

[9] L. Yang, R. Fassihi, Int. J. Pharm. 1997, 155, 219.

[10] T. Zhou, H. Lewis, R. E. Foster, S. Schwendeman, J. Controlled Release 1998, 55, 281.

[11] F. Ndindayino, C. Vervaet, G. van den Mooter, J. P. Remon, Int. J. Pharm. 2002, 235, 159.

[12] L. Yang, R. Fassihi, J. Pharm. Sci. 1996, 85, 170.

[13] C. Remuñán-López, A. Portero, J. L. Vila-Jato, M. J. Alonso, J. Controlled Release 1998, 55, 143.

[14] Y.-I. Jeong, J.-B. Cheon, S.-H. Kim, J.-W. Nah, Y.-M. Lee, Y.-K. Sung, T. Akaike, C.-S. Cho, J. Controlled Release 1998, 51, 169 .

[15] J. J. Sousa, A. Sousa, M. J. Moura, F. Podczeck, J. M. Newton, Int. J. Pharm. 2002, 233, 111.

[16] G. Ch. Charalambopoulou, E. S. Kikkinides, K. G. Papadokostaki, A. K. Stubos, A. Th. Papaioannou, J. Controlled Release 2001, 70, 309.

[17] C. M. Vaz, P. F. N. M. van Doeveren, R. L. Reis, A. M. Cunha, Polymer 2003, 19, 5983.

[18] R. Seal, "Industrial Soya Protein Technology", in: Applied Protein Chemistry, R. Grant, Ed., Applied Science Publishers Ltd, London 1980, p. 87.
[19] S. H. P. Ferreira, J. A. G. Arêas, J. Food Sci. 1993, 58, 378.

[20] G. A. Silva, C. M. Vaz, O. P. Coutinho, A. M. Cunha, R. L. Reis, J. Mater. Sci.: Mater. Med. 2003, in press.

[21] K. Panduranga Rao, J. Biomater. Sci., Polym. Ed. 1995, 7, 623.

[22] K. Tomihata, K. Burczak, K. Shiraki, Y. Ikada, "Polymers of Biological and Biomedical Importance", ACS, Washington 1994.

[23] A. G. A. Coombes, V. Breeze, W. Lin, T. Gray, K. G. Parker, T. Parker, Biomaterials 2001, 22, 1.

[24] A. A. Dinerman, J. Cappello, H. Chandehari, S. W. Hoag, J. Controlled Release 2002, 82, 277.

[25] S. A. Hogan, B. F. McNamee, E. D. O'Riordan, M. O'Sullivan, J. Agric. Food Chem. 2001, 49, 1934.

[26] S. J. Lee, M. Rosenberg, Int. J. Pharm. 2000, 205, 147.

[27] G. E. Romanos, J. R. Strub, J. Biomed. Mater. Res. 1998, 39, 462.

[28] K. Weadock, R. M. Olson, F. H. Silver, Biomater. Med. Dev. Artif. Organs 1983, 11, 293.

[29] C. M. Vaz, L. A. de Graaf, R. L. Reis, A. M. Cunha, "Polymer Based Systems on Tissue Engineering, Replacement and Regeneration", Vol. 86, Kluwer, Dordrecht, The Netherlands 2003, p. 93.

[30] C. M. Vaz, M. Fossen, R. F. van Tuil, L. A. de Graaf, R. L. Reis, A. M. Cunha, J. Biomed. Mater. Res. 2003, 65A, 60.

[31] C. M. Vaz, L. A. de Graaf, R. L. Reis, A. M. Cunha, Polym. Degrad. Stab. 2003, 81, 65.

[32] C. M. Vaz, M. Fossen, R. F. van Tuil, L. A. de Graaf, R. L. Reis, A. M. Cunha, J. Macromol. Sci., Phys. 2002, B41, 33.

[33] C. M. Vaz, P. F. N. M. Van Doeveren, R. L. Reis, A. M. Cunha, Biomacromolecules 2003, 4, 1520. 